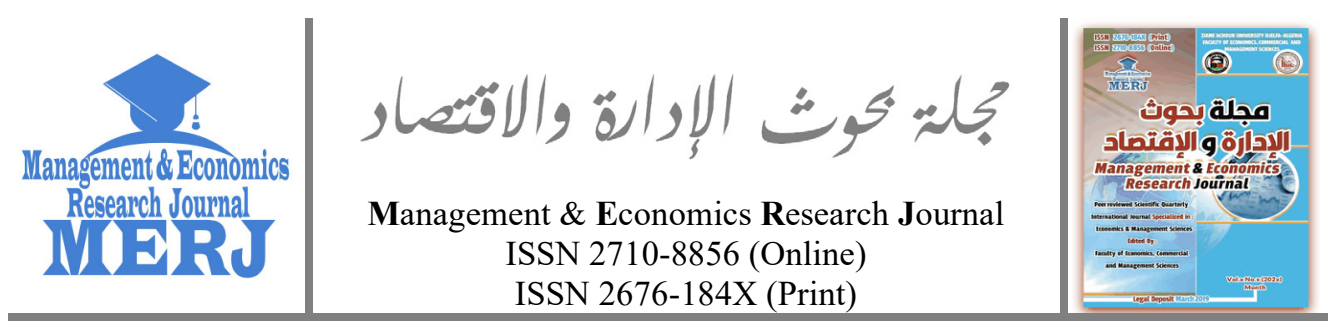

Vol. 3 No. 1 (2021), pp. 1-24

https://doi.org/10.48100/merj.2021.152

Check for updates

\title{
Internationalization of Bulgarian Tourism Business
}

\author{
Tanya Gorcheva ${ }^{1 \bullet}$
}

${ }^{1}$ Professor Doctor of Science, D. A. Tsenov Academy of Economics, Svishtov (Bulgaria)

$\triangle$ t.gorcheva@uni-svishtov.bg

Received: 22-01-2021

Accepted: 01-03-2021

Published online: 02-03-2021

\section{How to Cite:}

Gorcheva, T. (2021). Internationalization of Bulgarian Tourism Business. Management \& Economics Research Journal, 3(1), 1-24. https://doi.org/10.48100/merj.2021.152

\section{Abstract:}

This research aims to trace the internalization process of the tourism business over the last decades in our country. Several foreign economic factors have reasoned it by virtue of the open character of our national economy, the course of the transition economy reforms, and the peculiarities of the Bulgarian economy EU integration. The relation (internationalization of business - the internationalization of the national economy) is studied in different directions and methodologies, but in the present study, an adapted version of the method developed by Alan Rugman is applied. The primary approach is based on comparing the degree of internationalization in the national economy and the degree of internationalization of a specific type of business. The degree of internationalization is measured with the help of variables and a system of indicators, which are directed respectively to the business environment of the Bulgarian economy and the specifics of the Bulgarian tourism business. As analysis findings of the processes of internationalization in the context of tourism, it is concluded that these processes play an essential role in determining the position of Bulgarian

\footnotetext{
- Corresponding author: D. A. Tsenov Academy of Economics, Svishtov (Bulgaria).

[ $\square$ t.gorcheva@uni-svishtov.bg]
}

(C)2021 the Author(s). This is an open-access article distributed under the terms of (CC BY-NC 4.0) which permits use, distribution and reproduction in any medium, provided the original work is properly cited and is not used for commercial purposes. 
tourism in its inevitable competitive opposition to other tourist destinations and their business. The limitation has been identified in two periods of research on the degree of internationalization of business - the first covers seven years before Bulgaria's accession to the EU, and the second period - is almost ten years after the signing of the membership agreement. The practical implication of the study is that the increasing degree of internationalization of the tourism business in our country complements the overall result of the internationalization of the Bulgarian economy. This is especially clear in the second observed period of the study, which is expected to achieve a general synergy effect for the economy as a whole. The originality of the research consists in the adaptation and approbation of a known methodology for studying the internationalization processes to the specifics of the tourism business and a given economy, such as the Bulgarian one, for two separate periods.

Keywords: Tourism Business, Internationalization of the Tourism, Degrees of Internationalization.

JEL Codes: Z30, Z32, F62.

\section{Introduction}

The issues related to tourism internationalization are topical and, simultaneously, complex and debatable as they relate to the processes of national economy transformation due to internationalization. The complexity of studying the internationalization processes stems from the divergent interests of the business stakeholders. The efforts of business stakeholders are aimed at increasing revenues and improving profitability. The state authorities and administration pursue a government policy that strives to maintain a coalition of interests in favor of all sectors and industries in the national economy, observing the rules of market competition. Public interests are represented by different local, public, and non-governmental organizations, and because they are heterogeneous, they are often not united.

Modern internationalization processes are characterized by a high degree of dynamism. Internationalization describes changes that occur due to the rapid development of scientific and technological progress and the socioeconomic development of individual economies, which lead to a change in their status and importance within the modern international economic system. It occurs as a comprehensive trend (Mirković, 2000) in our time due to the nature and peculiarities of the reproductive cycle, marked by the desire to improve the welfare and, along with it, the expectations for the development and progress of the social systems, under 
the conditions of the growing importance of the services sector. This trend contributes to opening economies in search of forms and means to solve the problems associated with modern resource security and contemporary living standards.

In the first two decades of the 21 st century, some factors have become a priority for social development. An intensively functioning business model is imposed, in which the effect is derived not from the scale but the quality of the business. This changes the type of interconnectedness of economies. From being based on territory, it becomes based on ideas. The change in the resource conditionality of the interconnectedness causes new essential characteristics in the processes of modern internationalization and its specific manifestations (Broga, 2012). In our time, the forms of business internationalization directly correspond to the production and trade of services. Claiming that services are displacing industrial production seems inaccurate (Tan, 2016), but there is no denying the growing importance of this sector within the frameworks of the individual national economies and its growing share in international trade. Thus, for example, in developed economies, over $60 \%$ of GDP is created in the services sector. In OECD Member Countries, the share of employment in the services sector ranges between $65-77 \%$ (UNCTAD, 2010). As a result of the internationalization process, industrial production intertwines in its classical form with services, in which the competitiveness of individual companies or products acquires new meaning through the prism of the (tangible-intangible product) ratio. Business internationalization is a complex concept. Therefore, in the tourism business, as part of the services sector, it is interpreted both from a theoretical point of view and from the point of view of practical implementation. The tourism business worldwide is one of the fastest-growing in the field of services. According to the World Travel and Tourism Council (WTTC), the average annual growth rate of the world economy in 2018 was $3.2 \%$, while that of tourism was $3.9 \%$ (WTTC, Regional and world report). The gross domestic product produced by this business globally amounts to 2.8 trillion USD for 2018. Its share accounts for $10.4 \%$ of the total GDP created in the world in the same year. One in five jobs created worldwide is in tourism and travel. This highlights the need to analyze the processes occurring in the tourism business and explains the interest in studying its degree of internationalization.

In tourism, internationalization is often associated with product and destination competitiveness (Dupeyras \& MacCallum, 2013). Experts argue that business success is due to specific products that have been successful on the international market. That is why the products identified with a certain brand are most often identified with the destination that offers them. 
Thus, the competitiveness aspects in the field of tourism are linked to the attractiveness of the destination and the successful performance of the tourism business in the international market.

After setting out the issues related to determining the degree of internationalization, we should set the parameters of this study. The aim is to determine the degree of internationalization of the tourism business in Bulgaria in terms of inbound travel against the background of the internationalization of the economy as a whole. We define the tourism business in our country as the object of this analysis. The processes of internationalization, affecting the country's economy as a whole and, in particular, the tourism business, is defined as the subject of the study. On this basis, we formulate the thesis about the relative independence of the internationalization processes taking place in the economy of Bulgaria and its tourism business, although they are mutually bound and conditioned.

\section{Significance of the issue and elaboration of the topic of tourism business internationalization}

Successful market positions in the international market are becoming a strategic advantage under internationalization. They are based on the tourism product's competitiveness, the destination's attractiveness, and the advantages offered by the business environment. In cases when tourism is developing as an export-oriented sector of the national economy, the success of this business indicates not only its competitiveness but also the degree of its internationalization. The following specifics characterize the process of internationalization of the modern tourism business:

- The first one is related to the fact that tourism is a profitable economic activity. For example, in recent years, the USA has made about 84 billion USD annually, France 31 billion USD, Italy 27 billion USD, and Spain about 33 billion USD from rendering tourist services to foreign guests. The average annual per capita income from tourism for countries neighboring Bulgaria for 2015-2019 is 985 USD for Croatia, 1048 USD for Greece, and 273 USD for Turkey (UNWTO, 2019).

- The second characteristic outlines this process's rapid but uneven development. This is determined by the different levels of socioeconomic development of the different countries and regions that prioritize the tourist business. The mass tourism business model in developed industrial countries has best shown its economic and social advantages. Over time and with the expansion of business scale and the advantages, this process showed several disadvantages 
that cause anomalies in both the recipient and emitting countries' social, environmental, and economic development (WTTC, 2021).

- The third characteristic defines the interaction between the development of the tourism business and its internationalization. Tourism business as a specific industry is a part of the service sector which includes activities of diverse nature. For countries that develop international tourism, effects are generated related to the population's well-being and the structural profile of the entire economic complex. In this sense, many external factors determine international tourism's economic effect.

The development of the tourism business in Bulgaria in recent decades has been determined by several external economic factors under the open nature of our national economy, as well as by the peculiarities of integrating the Bulgarian economy into the EU. For this reason, we have grounds to believe that the search for objective arguments for determining the degree of internationalization within the Bulgarian tourism business is a serious motivation, as well as a challenge where the problems and difficulties in its development must be viewed in parallel with the achievements and traditions in this sphere. The importance of the degree of tourism internationalization is supported by the fact that in a multinational economic community such as the EU, the growing interdependence emphasizes the comprehensive competitiveness of the Bulgarian tourism business and the attractiveness of Bulgaria as well (business destination). At the same time, the degree of economy internationalization should be distinguished from the specific business internationalization, although they are mutually conditioned. Moreover, there is a difference in the degree of the ongoing internationalization process, where the economy can be characterized by a high degree of internationalization, while the degree of specific business internationalization is limited.

The essential characteristics of business internationalization are linked to the possibility of reaping the benefits of the participation of the national economy in the various forms of international business. In this sense, internationalization offers opportunities for progress. However, the processes of business internationalization do not flow smoothly (Corfu \& Nistoreanu, 2006). The openness of the economy to the rest of the world also implies the transmission of economic disturbances that would generate destabilization in the national economy. The binding of the national economy with the development of the tourism business as its priority sector is determined by many peculiarities. For this reason, the higher degree of tourism business internationalization compared to the average level of the other types of businesses cannot push the whole economy so that it will 
make progress. In economies that can be cited as a good example, the positive effects of tourism internationalization complement those achieved in the other types of businesses, and there is a general synergistic effect due to the developed infrastructure and economic potential of the economy as a whole.

The (internationalization of business - internationalization of the national economy) interdependence is studied in different trends (Balaguer \& Cantavella-Jorda, 2002; Camisón \& Forés, 2015). For example, the first trend draws a parallel between the destination's endowment of resources facilitating one form or another in product offering and its international appeal (Porter, 1990; Dwyer, Mellor, Livaic, Edwards, \& Kim, C., 2004). This interrelation highlights the interaction between the comparative advantages and the international competitiveness within the specific business and economy, respectively, the advantages of its business environment. Each form of internationalization requires a specific way of measuring and reflecting the degree of its dynamics. In our time, the forms of internationalization of business directly correspond to the production and trade in services. This process reveals its potential over time and leads economies to change individual and collective identities by contributing to overcoming established stereotypes of thinking and behaving from the past (Fenestra, 2008) and offers hitherto unknown opportunities for prosperity due to cooperation, generating several effects.

The experts of the World Economic Forum (WEF) work on another trend - measuring the degree of internationalization of the tourism business based on the advantages of the tourism destination and the business environment with which it develops. This methodology includes three main indices: (Regulatory framework of the tourism business), (Business environment and tourism infrastructure) and (Natural, human and cultural resources for the tourism business). The methodology of the World Economic Forum aims to prepare a ranking according to which each country can identify the strengths and weaknesses of its tourism business, as well as the business environment in which the tourism destination operates (World Economic Forum, 2007). In this sense, the priority is not to measure the degree of internationalization of the tourism business but to reveal the interdependence between the framework that the national economy creates for internationalization and similar processes in the tourism business.

A third trend for assessing the degree of internationalization of the tourism business in different countries is proposed by the World Travel and Tourism Council (WTTC). The Council's expert centers monitor the processes of internationalization based on the competitiveness of the tourism business in the individual tourism destinations according to a 
methodology, including indicators for comparison in the following main areas (WTTC, 2017): price competition; the humane side of the tourism business; infrastructure; environment; level of technology and innovation; qualification of human resources; degree of openness of the destination; social characteristics of the destination. The application of this methodology allows for the parallel consideration of the degree of internationalization, both for the business environment of the respective economy and the degree of internationalization of the tourism business itself.

A fourth trend for interpreting the internationalization process is based on comparing the degree of internationalization between the national economy (considered a business destination) and the specific business type in their export orientation. For this purpose, the indicators used are related to the realized advantages of internationalization depending on the degree of connection between the economic entities from the national and international business environment. The method derives the businessspecific advantages (BSAs) and the country-specific advantages (CSAs) on a matrix basis. It has been developed and applied in many studies (Rugman, $1979 ; 1981 ; 2005)$ as a way to derive the degree of internationalization for individual economies, viewed as business destinations, as well as for the economic operators in the specific business environment.

These research trends give us reason to conclude that the internationalization-specific advantages relationship requires detail when studying the aspects of the business environment and the individual types of business in the respective environment to assess their implementation in practice. The advantages obtained as a result of the attractive business environment within the specific national economy define it as an attractive place for foreign investors, and this opens opportunities for a higher degree of internationalization. On the other hand, the advantages of the tourism destination, incl. the quality and competitiveness of its products and services, define it as attractive to foreign tourists - in terms of the international tourism market. It is no coincidence that international tourism is categorized as an invisible export for the economy, a recipient of inbound tourism flows. Identifying the two sides related to the internationalization processes in the context of tourism has an important role in determining the positions of Bulgarian tourism in its inevitable competitive opposition to other tourism destinations and their business, which have similar tourism resources and develop products close to those of our country.

In summary, we conclude that as a result of internationalization, industrial production intertwines in its classical form with services, where the competitiveness of individual companies or products takes on new meaning through the prism of a tangible-intangible product. The growing 
importance of services lies in the deepening division of labor and the expanding specialization in specific production areas based on technical and technological innovation

\section{Method of studying and selecting the variables to determine the degree of internationalization}

As a concept, the tourism business is associated with the fact that, per se, it is a relatively independent economic system within the national economy, which reveals its economic nature. The combination of the need for rest and the desire to rationalize leisure time in a pleasant and useful way creates social needs that are met through exercising diverse but interrelated activities concerning the production of goods and services that are provided on a market basis to this part of consumers who are defined as tourists. In the whole set of production and technological relationships, factors, and resources, tourism is essentially considered an economic activity, differentiated as an independent business form (Athiyaman, 1997; Dritsakis, Athanasiadis, 2000), which is part of the services sector. The approach for defining tourism as an independent business highlights the cyclical production of tourism products and services aimed at achieving specific economic outcomes - generating income, making a profit, creating jobs, increasing assets, maintaining positive financial results, transferring investments, etc. Like any business, it can be export-oriented.

To determine the degree of internationalization of the Bulgarian tourism business and the economy, we apply a method different from those of the World Economic Forum and the World Travel and Tourism Council. The approach, based on the comparison between the degree of internationalization in the national economy (Country specific advantages CSAs) and the degree of internationalization of a specific type of business (Business-specific advantages - BSAs) - in this case, the tourism business developed in the respective national business environment, is viewed as an adapted version of the method developed by Alan Rugman (Rugman, 2005). This method enables us to determine the extent to which the tourism business operating in the Bulgarian national business environment is characterized by a degree of internationalization different from that of the national economy as a whole, taking into account the specific forms of internationalization itself, namely: total production, in particular, its export orientation and the net amount of foreign direct investment.

The degree of internationalization is measured using variables and a system of indicators, which are directed respectively to the business environment of the Bulgarian economy and the specifics of the Bulgarian 
tourism business (Table 1). As seen from the Table, the specific advantages of the tourism business in Bulgaria and the national economy will be derived based on variables related to the production volume, exports, and foreign direct investment (FDI). It should be noted that both the NSI methodology and the methodology established by the World Tourism Organization, known as the Tourism Satellite Account, are considered. This is necessitated by the need to distinguish total production in the hotel and restaurant business for external residents from the total production in the hotel and restaurant business and related industries, which emphasizes the export orientation of the tourism business.

Table 1. Variables to determine the degree of internationalization

\begin{tabular}{ll}
\hline $\begin{array}{l}\text { Variables to study the national economy } \\
\text { of Bulgaria }\end{array}$ & Variables to study the Bulgarian tourism business \\
\hline $\begin{array}{l}\text { Gross domestic product, in million BGN } \\
\text { Value of Bulgarian export, in million }\end{array}$ & $\begin{array}{l}\text { Total production in the hotel and restaurant business, in } \\
\text { million BGN } \\
\text { RGN }\end{array}$ \\
$\begin{array}{l}\text { Revenue from international tourism, in million BGN } \\
\text { BGN }\end{array}$ & Net FDI - hotels, and restaurants, in million BGN \\
\hline
\end{tabular}

The variables describing international trade transfer reveal the relation between the specific economy and the rest of the economies in the world, which stems from the need to exchange factors of production, services, and goods due to international specialization. The current study focuses on exports to reveal the extent to which the economy is exportoriented. The variables related to the transfer of investments, respectively FDI, are more closely linked to the attractiveness of the environment, where they find a profitable field for investment. For this reason, they contribute in a specific way to determining the degree of internationalization.

The analysis is based on quantitative values and involves studying one-dimensional variables, which determine the share and, through it, the importance of the tourism business in the country's economy as one of the export industries, through which the degree of internationalization can be measured, first tracking the share of:

- The total production in the hotel and restaurant business for external residents to the gross domestic product of the country;

- The total production in the hotel and restaurant business and related industries to the gross domestic product of the country;

- Export revenues to the country's GDP;

- Revenues from international tourism to the revenues from our economy's exports; 
- Net foreign assets to the GDP of our economy;

- Net foreign assets in tourism to the total volume of FDI in the country.

Then the dynamics in the internationalization process occurred respectively in the economy as a whole and in particular in the tourism business of Bulgaria.

The data cover 2000-2018, and the duration selection is not random. The time range can be divided into two observation periods. The idea is to highlight the differences in the trend for the degree of internationalization depending on Bulgaria's membership in the EU. The first observation period from 2000 to 2009 is associated with the pre-accession process, which our country went through as a preparatory stage for EU membership. It should be noted here that Bulgaria became a member of an integration system in 2007, but 2008 and 2009 are associated with the global financial crisis, due to which the effects of its full membership began to manifest themselves after the crisis was overcome. The second observation period lasting from 2010 to 2018, makes it possible to assess the impact of membership on the degree of internationalization for the whole economy and the tourism business in particular.

As a result of the above regarding the selection of an adequate method of studying the degree of internationalization of the Bulgarian tourism business, it becomes clear that the applied method makes it possible to track bilaterally:

- The degree of connection of the Bulgarian economy with the other economies through exports;

- The importance of the Bulgarian tourism business, as an export industry, for the economy of Bulgaria;

- The contribution of the tourism business as an export industry to the economy of Bulgaria, incl. in terms of its multiplier effect on other industries;

- To what extent is our economy attractive as an economic destination to foreign investment in general, and to what extent tourism as a business is attractive to foreign investors?

\section{Determining the degree of internationalization of the Bulgarian tourism business}

\subsection{Importance of the tourism business for the economy of Bulgaria}

Since its inception as an independent economic system with the parameters of industrial activity, tourism in our country has been 
characterized by international and export orientation, which is facilitated on the one hand by the favorable natural resources, and on the other hand by the material base built over the years and consistent with the scale of mass organized tourism. The model, which our country has inherited from the years of socialism and as a result of the development of mass tourism, is oriented towards the organized inbound flows of tourists, mainly to our Black Sea resorts in summer and to our mountain resorts in winter. Market reforms related to the restructuring of the tourism business in our country have generated a number of changes. The restructuring and transformation in the years of transition have not changed the characteristics mentioned above of tourism in our country, although the reforms in this area have caused many problems and contradictions. However, the great importance of the tourism business for the Bulgarian economy should not be denied. This significance is revealed based on specific facts: according to the World Travel and Tourism Council data, the share of the total tourism product to the country's GDP for 2018 amounts to $11.7 \%$. Nearly 350 thousand people are employed in the tourism business in our country, and their number is expected to rise to 400 thousand by 2029 . The share of revenues from international tourism to the total amount of exports from Bulgaria for 2018 amounts to $12.3 \%$, which puts the tourism business in one of the leading positions in export-oriented industries. The export orientation of the Bulgarian tourism business is confirmed by the fact that the expenditure incurred by foreign tourists who visited the destination Bulgaria in 2017 exceeded five times the expenditure of Bulgarians for domestic tourism. It should be emphasized that the tourism business in our country is developing as a form of international business and is explicitly active, as inbound tourism flows generate twice as much revenue as Bulgarian tourists' expenditure for outbound travel abroad (WTTC Regional reports, 2018). EU countries are the main generating source of tourism flows to Bulgaria, with Romania and Germany being particularly important emitters. An important emittent of tourists are also the countries of Southeast Europe, such as Turkey, Macedonia, and Serbia (Ministry of Tourism, 2019). Russia is one of the traditional markets where the Bulgarian tourism product is known and attractive, although, in the last decade, it has been outside the first five countries sending tourists to our country.

Here we should note that the Bulgarian tourism business has undergone many positive changes in the market and structural reforms undertaken in the economy. The existing hotel facilities have been reconstructed, and the category of many hotels has been raised. For example, for the last 20 years, two-star hotels have disappeared from the Black Sea coast and the major mountain resorts. The share of three-star 
hotels is over $45 \%$, four-star hotels exceed $35 \%$, and the newly-built hotels are in the over-four-star category (Capital, 2015). There are positive changes in some of the major urban centers of our country. Thus, for example, in Sofia, the number of 4 and 5-star hotels is increasing, and so is the number of beds, the number of nights spent, and the revenue from foreigners checking in. A total of 1,605,179 overnight stays were recorded for 2017, of which over 1 million were foreigners. The four- and five-star hotels in Sofia share BGN 93.4 million of the total and BGN 77.4 million of the money from foreign citizens (Dnevnik, 2016). These changes are due not only to the undertaken market reforms and the growing competition in the Bulgarian market but also to some external factors. In recent years, two low-cost European airlines have opened bases in our country, thus starting the service of new airlines. For example, the Irish airline Ryanair opens 11 new destinations with initial flights from various airports in Bulgaria. Wizz Air begins to maintain regular flights to its established destinations during the peak season and throughout the year (EC.Europa.EU, 2017). This contributes to the growing interest in our country's main urban tourism destinations, such as Sofia, Plovdiv, and Burgas.

The reforms carried out in Bulgaria in the years of transition to a market economy have positively impacted the tourism business, but they do not solve all problems. One problem is the efficiency of the business and the associated profitability. According to Eurostat data for 2019 tracking the expenditure that each foreign tourist makes by visiting these destinations, it is found that for Bulgaria, Hungary, and Romania, they are almost three times lower than those for Croatia, Spain, and Italy (Tourism Satellite Accounts in Europe, 2019). The comparison indicates which tourism destinations are highly profitable and which do not favor our country. This fact is due to many complex reasons. Thus, we conclude that the abovedescribed formula, according to which the Bulgarian tourism business operates, does not offer an opportunity to combine high profitability with the new quality of the investments made. If we track the last five years, during which new external influences appeared, such as the war in the Eastern Mediterranean, the hostility between Russia and Ukraine, and the wave of refugees, we can say that Bulgarian tourism is doing well. These events redirected some of the tourism flows to our country, which did not improve Bulgarian resorts' level of service and quality, However, the business benefited from the increased number of accepted tourists.

The comprehensive analysis made on the state and importance of the Bulgarian tourism business proves that it is developing as a living organism and reflects both the restructuring of the national economy and the changes in the market situation on the international tourism market, where: 
- It continues to be an important part of the national economy of our country and, in recent decades, has been characterized as one of the few successfully developing types of businesses in our country;

- The impact of structural reforms in the national economy transforms the essence of the tourism business and places it in the competitive environment of the open international tourism market;

- Despite the attempts to become highly profitable, the Bulgarian tourism business retains its main focus on offering standardized package products at relatively low-price ranges, available for mass tourism flows to our country, mainly from different European countries;

- Thus, the Bulgarian tourism business retains its essence of being export-oriented.

The above-stated leads us to the need to outline the main trends in the degree and dynamics of the processes of internationalization, both of the Bulgarian economy as a whole and of the tourism business in particular, which enables us to reveal the interaction between the two processes and to highlight the ways of impact and stimulation.

\subsection{Outcomes of the empirical study on the degree of internationalization of the Bulgarian tourism business}

The approach based on comparisons to determine the differences in the degree of internationalization of the national economy (CSAs) and the specific type of business (Business-specific advantages - BSAs) enables us to derive the specific advantages of the business regarding the general trend of development of the internationalization process of the economy as a whole.

As has already been found, the tourism business, developed within the framework of the Bulgarian economy, has always been export-oriented. What is of interest in the last part of this study is to find out the difference between the degree of internationalization, taking into account the different stages in the operation of the national economy before and after its EU membership.

Based on the database of the selected and the above indicators for the period 2000-2018, the comparative analysis shows the following: 


\subsubsection{Results of the analysis of the structural indicators in determining the degree of internationalization for the first observation period}

As can be seen from sub-tables $2 \mathrm{~A}$ and $2 \mathrm{~B}$, the share of the total production in the hotel and restaurant business to the GDP of Bulgaria is constantly increasing, which confirms the statement from the previous paragraph about the successful operation and development of Bulgarian tourism business within the national economy, both in the period before its full EU membership and in the first decade of membership. Undoubtedly, this type of business has a positive multiplier effect on the other industries of the economy.

Regarding the indicator share of the total production in the hotel and restaurant business for external residents to GDP, there is a difference in the two observation periods. The data for the pre-accession period show that this share ranges between 2.54 and $3.46 \%$, while for the next period, it ranges widely $(4.1-8.4 \%)$. The commonality between the two observation periods is the tendency to increase this share of the economy's GDP. This means an increasing export orientation of the tourism business.

When we analyze the data by the indicator showing the share of export revenues to the GDP of Bulgaria, we find that this share remains relatively stable in the first observation period. However, as a value, it is quite limited. During the second period, however, there is a sharp increase in the share, which suggests that Bulgaria's full membership in the EU increases the degree of openness of the economy, both in foreign trade turnover and in international cooperation with EU countries. When we compare the total share of exports to GDP with the share of exports realized through tourism, we will find that:

- During the first observation period, the total share of exports to GDP is more limited than the share of exports from the tourism business, and in only two of these years, the share is almost equalized. This means that during this period, tourism is one of the few exportoriented businesses in our country. 
Table 2. Structural indicators in determining the degree of internationalization

2A. First observation period

\begin{tabular}{|c|c|c|c|c|c|c|c|c|c|c|}
\hline Indicators & 2000 & 2001 & 2002 & 2003 & 2004 & 2005 & 2006 & 2007 & 2008 & 2009 \\
\hline Share of export earnings to GDP, $\% *$ & 8.4 & 7.3 & 7.3 & 8.9 & 8.9 & 8.8 & 8.6 & 8.4 & 9.1 & 17.7 \\
\hline $\begin{array}{l}\text { Share of international tourism revenue } \\
\text { to export earnings, } \% * * *\end{array}$ & 10.7 & 9.7 & 10.5 & 11.5 & 12.2 & 10.6 & 8.8 & 9.8 & 9.7 & 11.7 \\
\hline $\begin{array}{l}\text { Share of net foreign assets to GDP, } \\
\%^{* *}\end{array}$ & 3.7 & 6.6 & 9.1 & 14.2 & 15.3 & 19.6 & 23.5 & 29.8 & 27.5 & 26.4 \\
\hline $\begin{array}{l}\text { Share of the total production in the } \\
\text { hotel and restaurant business for } \\
\text { external residents to GDP, \%* }\end{array}$ & 2.6 & 2.6 & 2.5 & 2.8 & 2.9 & 3.0 & 3.1 & 3.4 & 3.5 & 3.3 \\
\hline $\begin{array}{l}\text { Share of the total production in the } \\
\text { hotel and restaurant business and } \\
\text { related industries to GDP, } \% * * *\end{array}$ & 13.5 & 13.3 & 13.9 & 14.8 & 13.4 & 14.7 & 15.0 & 14.5 & 14.9 & 15.2 \\
\hline $\begin{array}{l}\text { Share of the net foreign assets in } \\
\text { tourism to the total volume of FDI in } \\
\text { the country **** }\end{array}$ & 3.3 & 4.6 & 3.6 & 3.4 & 2.3 & 2.7 & 2.5 & 1.8 & 1.9 & 1.9 \\
\hline \multicolumn{11}{|c|}{ 2B. Second observation period } \\
\hline Indicators & & 2010 & 2011 & 2012 & 2013 & 2014 & 2015 & 2016 & 2017 & 2018 \\
\hline Share of export earnings to GDP, $\% *$ & & 21.4 & 38.2 & 49.1 & 53.4 & 51.9 & 49.6 & 49.7 & 52.1 & 49.8 \\
\hline $\begin{array}{l}\text { Share of international tourism revenue } \\
\text { export earnings, } \% * * *\end{array}$ & & 9.5 & 7.9 & 7.1 & 7.4 & 7.2 & 8.9 & 9.5 & 10.8 & 12.1 \\
\hline Share of net foreign assets to GDP, $\% * *$ & & 37.3 & 45.6 & 45.4 & 45.1 & 45.3 & 44.5 & 51.2 & 50.7 & 51.5 \\
\hline $\begin{array}{l}\text { Share of the total production in the } h \\
\text { and restaurant business for exter } \\
\text { residents to GDP, \%* }\end{array}$ & otel & 4.1 & 5.8 & 7.0 & 7.4 & 7.2 & 6.7 & 8.4 & 7.7 & 7.1 \\
\hline $\begin{array}{l}\text { Share of the total production in the } \mathrm{h} \\
\text { and restaurant business and rela } \\
\text { industries to GDP, } \% * * *\end{array}$ & $\begin{array}{l}\text { lotel } \\
\text { ated }\end{array}$ & 17.4 & 18.2 & 17.3 & 18.5 & 18.3 & 19.1 & 19.2 & 18.9 & 20.3 \\
\hline $\begin{array}{l}\text { Share of the net foreign assets in tourisn } \\
\text { the total volume of FDI in the country ** }\end{array}$ & & 1.8 & 2.2 & 2.4 & 2.3 & 2.1 & 1.7 & 1.5 & 1.3 & 1.1 \\
\hline
\end{tabular}

* Calculated according to data of the NSI, at: https://www.nsi.bg/bg/content/2206/bvp -

proizvodstven-metod-natsionalno-nivo and https://www.nsi.bg/bg/content/2000/satelitni-smetki-za-

turizma

** Calculated according to data of the NSI and BNB, at:

http://www.bnb.bg/Statistics/StStatisticalBD/index.htm \& http://www.nsi.bg/otrasal.php?otr=10

*** Calculated according to data of the NSI and the Ministry of Tourism, at:

http://www.tourism.government.bg/bg/kategorii/statisticheski-danniand

https://www.nsi.bg/bg/content/2206/bvp-proizvodstven-metod-natsionalno-nivo

**** Calculated according to data of the NSI and BNB, at:

http://www.bnb.bg/Statistics/StStatisticalBD/index.htm 
Table 3. Dynamics indicators in determining the degree of internationalization 3A. First observation period

Dynamics indicators, in \%

\begin{tabular}{|c|c|c|c|c|c|c|}
\hline $\begin{array}{l}\text { ¿̊ } \\
\stackrel{1}{-} \\
\stackrel{ }{8}\end{array}$ & 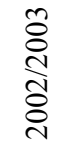 & 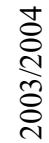 & 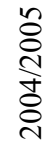 & 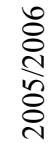 & 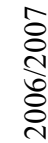 & \\
\hline
\end{tabular}

Dynamics in the value of the gross domestic product *

$\begin{array}{lllllllll}3.8 & 4.4 & 5.6 & 6.6 & 6.3 & 6.2 & 6.3 & 6 & -5\end{array}$

Dynamics in the value of the total production in

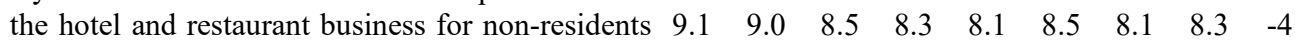

$* * *$

$\begin{array}{lllllllll}4.3 & 9.2 & 12.0 & 13.3 & 18.2 & 19.4 & 17.0 & 8 & -12\end{array}$

Change in the volume of FDI total for the country, net value $* * * *$

$\begin{array}{lllllllll}11.0 & 9.0 & 15.1 & 11.6 & 16.3 & 15.7 & 18.4 & 19 & -7\end{array}$

Change in the volume of FDI in tourism, net value

$\begin{array}{lllllllll}21.1 & 18.0 & 19.5 & 17.3 & 18.4 & 11.1 & 8.6 & 6 & -5\end{array}$ $* * *$

3B. Second observation period

Dynamics indicators, in \%

\begin{tabular}{|c|c|c|c|c|c|c|c|c|}
\hline 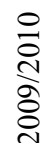 & $\begin{array}{l}\bar{\Xi} \\
\text { ㄱ. } \\
\text { o } \\
0 \\
0\end{array}$ & 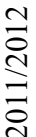 & 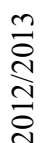 & 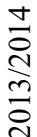 & \begin{tabular}{l}
$\stackrel{n}{\circ}$ \\
$\stackrel{N}{J}$ \\
\multirow{2}{*}{}
\end{tabular} & 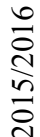 & $\begin{array}{l}\frac{1}{\circ} \\
\stackrel{N}{0} \\
\stackrel{0}{0}\end{array}$ & $\frac{\infty}{i}$ \\
\hline
\end{tabular}

$\begin{aligned} & \text { Dynamics in the value of the gross domestic } \\ & \text { product * }\end{aligned}$

Dynamics in the value of the total production in

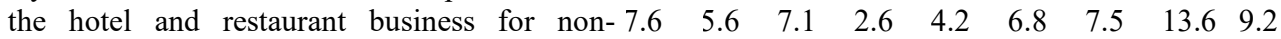

residents $* * *$

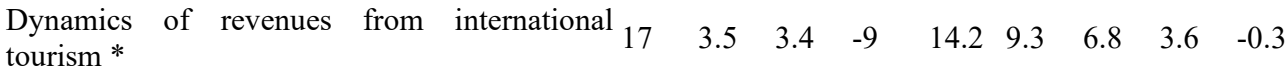

Change in the volume of FDI total for the $\begin{array}{llllllllll}-0.5 & 2.8 & 2.7 & -1.1 & 5.2 & 22 & 4.1 & 9.8 \\ \text { country, net value } * * * *\end{array}$

Change in the volume of FDI in tourism, net $\begin{array}{lllllllll}0.8 & 26.2 & 10.4 & 1.7 & -2.0 & -0.9 & -0.5 & -7.3 & -12\end{array}$ value $* * *$

- During the second period, the importance of tourism as an export industry is preserved, but along with it (probably due to its more intensive development and improved competitiveness), a number of other sectors and industries of our economy begin to operate as exporting.

As a result of the analysis of these indicators, it becomes clear that the increasing share of exports to the GDP for the second observation period shows that after the economic reforms and restructuring of the economy were completed, Bulgaria has identified the areas where there are competitive advantages, based on which it has increased its presence in foreign markets. In addition, the share of revenues from international tourism occupies a significant share of exports, which shows that tourism is one of the types of businesses in our country which operates successfully 
enough to create competitive services in foreign markets.

The tracking of the last pair of indicators -share of net foreign assets to GDP and share of net foreign assets in tourism to the total volume of FDI in the country shows that in the first period, the net amount of FDI to GDP is constantly increasing, which speaks of the increasing attractiveness of the Bulgarian economy for foreign investors, and thus of increasing the degree of internationalization of business destination Bulgaria. At the same time, the inflow of net foreign assets to tourism in Bulgaria is much more limited than the total inflow to our economy.

\subsubsection{Results of the analysis of the dynamics indicators in determining the degree of internationalization}

During the 2000-2007 observation period, the dynamics in the value of GDP show an upward trend (sub-tables $3 \mathrm{~A}$ and $3 \mathrm{~B}$ ). The same dynamics are observed with regard to the total production in the hotel and restaurant business. Moreover, its growth rates are rhythmic and higher than those with which the value of GDP increases. If the average annual growth rate in the value of GDP is $5.5 \%$, then the analogous rate of the value of total production in hotels and restaurants is $8 \%$. At the same time, the rates with which revenues from international tourism are increasing show not just an increase, but an average annual increase of $13 \%$, which implies a real expansion of the development of international tourism in our country. The same applies to the growth of FDI in our country, particularly the FDI that flows into Bulgarian tourism. Their average annual growth rate is $14 \%$. It is obvious that during this period, which is the eve of Bulgaria's EU membership, the interest of foreign investors in our country is increasing. During this period, two significant moments positively affect the inflow of FDI to Bulgaria, particularly tourism. The first is related to the increase in the number of hotels in the post-privatization process as new construction. In addition, we should emphasize the reconstruction of the already privatized hotels, in which some foreign tour operators participate, attracting tourists to the Bulgarian Black Sea coast. The second moment is related to the avalanche-like swelling of the real estate market during this period in our country when non-residents (mostly British and Russians) acquire property in Bulgaria's rapidly developing sea and ski resorts. During this period, a significant part of foreign investment in tourism is in the form of acquiring real estate by foreign nationals as a second residence (Dupeyras \& MacCallum, 2013). Undoubtedly, this is a result of the completed structural reforms of the economy, the successful negotiations for EU membership, and the rapidly developing construction on the Black Sea coast and 
mountain resorts in our country. Excluding the period of the financial crisis 2008-2010, during which a decline was registered, the growth by all indicators was resumed in the period 2010-2018.

During 2010-2018, the upward trend in the value of GDP was maintained, but the rates were lower than in the previous period. Namely, the average annual growth rate is $4 \%$. The same applies to the growth of total production in the hotel and restaurant business, whose rate amounts to $7 \%$ on average per year. The rates at which revenues from international tourism increase during this period amount to $3.5 \%$, but unlike the previous period, there is no smoothness and consistency, but sharp declines and jumps. For example, after the crisis period in 2010, a jump of $17 \%$ compared to the previous year was reported. The situation was similar in 2014 compared to 2013, with a significant rise in revenues from international tourism compared to the previous year. The reason for this lies in the financial collapse in which Greece finds itself and the restrictive measures taken by its government. As a result, some tourism flows are reoriented to Greece's neighboring countries, including Bulgaria. The next observed jump in revenues from international tourism was reported in 2015 compared to 2014. This fact is explained by the outflow of tourists from Bulgaria's other neighboring destination - Turkey. This period is unfavorable due to the refugee crisis's beginning, making Turkey an insecure tourism destination.

Tracking the dynamics of FDI in our country, in general, and in particular, the FDI that flow into Bulgarian tourism for the period 20102018, we find an ambiguous trend in both the first and the second indicator. However, the overall trend for the period is the average annual growth rate of FDI net inflows total for the country of $5.6 \%$. For example, the country's net FDI total decreased in two years during the observation period. After 2014 , there was uneven growth, with the highest jump compared to the previous year being recorded in 2015. On average, for the second observation period, a growth of $1.8 \%$ is reported in the volume of foreign investment in Bulgaria directed to tourism. This indicator also shows an uneven upward and downward trend, although there is an upward trend for the first part of the observation period (2010-2013) and a marked decline during the other part (2014-2018). We can look for an explanation for this outflow of foreign investment from tourism in our country during the indicated period in two directions. Firstly, our country's new construction rates, tourist sites, and housing are slowing down. Secondly, many foreigners who have acquired a property in the Bulgarian resort areas get rid of it.

Summarizing the results of analyzing the data on the Bulgarian 
economy in general and the tourism business in particular in our country, we find the general trend towards increasing the degree of internationalization. Despite this general trend, some specifics are found in the individual observation periods, namely:

- In the 2000-2007 period, the tourism business in our country was characterized by a higher degree of internationalization compared to the economy as a whole. Moreover, it stimulates several sectors and industries in the country that supply goods and services for tourism and, as a strong export industry, contributes to multiplying the effect of its development and economic growth. Let us point out that this period is a key moment in the economic and political development of the Bulgarian economy, related to the completion of market reforms and the preparation for EU membership.

- In the 2010-2018 period, there was a much more turbulent process of internationalization of the Bulgarian economy compared to the degree of internationalization of the tourism business in our country. It maintains its export orientation but falls much more often under the influence of factors external to the Bulgarian economy, as evidenced by the registered sharp declines and growth jumps. This is explained by the rapid opening of the Bulgarian economy to the EU due to the deepening of integration processes and its increasingly comprehensive integration with the other European economies. These processes affect not only tourism but also several other sectors and industries, which means that integration processes contribute to the transfer of negative impacts on the Bulgarian economy and, in particular, its tourism business, as well as many positive processes as a stimulus to increase competitiveness.

- Tracking the indicators reflecting the production, export, and capital parameters of internationalization, it is necessary to summarize that in the first observation period, the tourism business is the undisputed export industry of Bulgaria, but still not attractive enough for FDI as some other industries of the Bulgarian economy. This means that the degree of internationalization of the Bulgarian tourism business is realized based on the so-called invisible exports, while both FDI inflows and international trade contribute to the internationalization of the Bulgarian economy. During the second observation period, we found that the importance of FDI in highlighting the degree of internationalization in the economy of the country as a whole and, in particular, the tourism business is severely limited. The priority for increasing the degree of internationalization falls primarily on 
strengthening the export orientation, both for the national economy and for the tourism business of Bulgaria.

\section{Conclusion}

As a result, we can summarize the analysis and draw the following conclusions:

- The tourist business in Bulgaria is created on the model of massorganized tourism with an export orientation. Over the years, it has not remained in a constant state but has been developing in accordance with European integration processes - on the one hand and with market reforms - on the other hand.

- The internationalization processes are influenced by several external factors depending on the degree of openness of the economy. The more open it is, the stronger the external influences are.

- There is a difference in the degree of the ongoing internationalization process, where the economy can be characterized by a high degree of internationalization, while the degree of internationalization of the particular business is limited. External influences can change the degree of internationalization at these levels.

- In recent decades, the strongest influence on the processes of internationalization in Bulgaria has been its membership in the EU. The internationalization of the tourism business in our country is associated with the growth of invisible exports, while the internationalization of the national economy is based on both the growth of exports and foreign direct investment.

- In recent decades, the strongest influence on the processes of internationalization in Bulgaria has been its membership in the EU. The internationalization of the tourism business in our country is associated with the growth of invisible exports, while the internationalization of the national economy is based on both the growth of exports and foreign direct investment, and international cooperation is important. The study shows that internationalization processes proceed with different dynamics in tourism and the national economy.

- The above-stated and performed analysis leads to the conclusion that the effect of the increasing degree of internationalization of the tourism business in our country complements the overall result of the Bulgarian economy internationalization. This is especially clear in the second observation period of the study, and it is expected to 
achieve a general synergy effect for the economy as a whole.

The analysis, related to the specifics of internationalization in the sphere of tourist business, gives us grounds to draw some recommendations for expanding the research on the topic, namely:

- The internationalization processes enable countries with relative advantages in tourism to develop it to exceed the limited consumer potential on the national market. It is advisable to pay more attention to small and medium tourism businesses, as it needs more support than large corporations benefiting from internationalization. This necessitates the application of a policy that allows the national businesses to use the internationalization advantages but also to stop the negative influences of their going on the international market.

- The analysis of the economic nature of international tourism confirms that internationalization as a clearly defined variant for changing business characteristics must be studied both in the qualitative and quantitative aspects, which makes it necessary to work out an adequate system of indicators related not only to international trade with services, including tourist services and international capital transfer mainly in the form of foreign direct investments but also to modern forms of international cooperation, among which innovation cooperation has priority.

- The business environment factors determine various indications for realizing the tourist business in its international dimension - the external ones contribute to the stimulation of the competition, including the situations of world crisis. In contrast, the internal ones are connected with restructuring and improvement complied with good international practices. For this reason, future research on the topic is desirable to include aspects of the international competitiveness of the traded services, the tourist product, and the destination.

\section{Declaration of conflicting interests}

The author(s) declared no potential conflicts of interest with respect to the research, authorship, and/or publication of this article.

\section{References}

Abreu-Novais, M., Ruhanen, L., \& Arcodia, C. (2016). Destination competitiveness: What we know, what we know but shouldn't, and what we don't know but should. Current Issues in Tourism, 19 (6), 
492-512. https://doi.org/10.1080/13683500.2015.1091443

Athiyaman, A. (1997). Knowledge development in tourism: Tourism demand research, Tourism Management, 18(4), 221-228. https://doi.org/10.1016/s0261-5177(97)00009-5

Balaguer, J., \& Cantavella-Jorda, M. (2002). Tourism as an economic growth factor: The Spanish case. Applied Economics, 34 (7), $877-$ 84. https://doi.org/10.1080/00036840110058923

Broga, D. (2012). Justice and Inequality in the World Trading System: A Critical Assessment. Inquiries Journal, 4 (11). http://www.inquiriesjournal.com/a?id=712

Bulgarian National

Bank.

http://www.bnb.bg/Statistics/StStatisticalBD/index.htm

Camisón, C., Forés, B. (2015). Is tourism firm competitiveness driven by different internal or external specific factors? New empirical evidence from Spain. Tourism Management, 48, 477-99. https://doi.org/10.1016/j.tourman.2015.01.001

Corfu, A., \& Nistoreanu, P. (2006). Insights in internationalization of tourism firms. Amfiteatru Economic 8(19). https://www.researchgate.net/publication/4981984_insights_in_inter nationalization of tourism firms

Croes, Robertico \& Semrad, Kelly. (2018). Destination Competitiveness. https://www.researchgate.net/publication/327822042_Destination_C ompetitiveness

Dritsakis, N., \& Athanasiadis, S. (2000). An econometric model of tourist demand: The case of Greece, Journal of Hospitality \& Leisure Marketing, 7(2), 39-49. https://doi.org/10.1300/j150v07n02_03

Dupeyras, A. \&MacCallum N. (2013). Indicators for Measuring Competitiveness in Tourism: A Guidance Document, OECD Tourism Papers, No. 2013/02, OECD Publishing, Paris, https://doi.org/10.1787/5k47t9q2t923-en

Dwyer, L., Mellor, R., Livaic, Z., Edwards, D. and Kim, C. (2004) Attributes of Destination Competitiveness: A Factor Analysis.; Tourism Analysis, 9 (1-2), 91-101. https://doi.org/10.3727/1083542041437558

European Regional Development Fund - thematic guidelines for investment in tourism.

http://ec.europa.eu/regional policy/bg/policy/themes/tourism/

Fenestra, R. \& Taylor, A. (2008). International Trade, New York: Worth Publishers.

Gorcheva, T. (2012). Internationalization in the field of tourism business. Education and Science, 10, 16-18. 
Kirev, L. (2007). From internationalization to the globalization of the economy. Business management, 3, 60-61.

Metropolitan hotels in more. (September 4, 2016). https://www.capital.bg/biznes/kompanii/2016/09/04/2821618_stolic hni_hoteli_v_poveche/

Ministry of Tourism.

http://www.tourism.government.bg/bg/kategorii/statisticheskidanni/statisticheski-danni-2019

Ministry of Tourism. (2019). https://www.nsi.bg/bg/content/2206/бвппроизводствен-метод-национално-ниво

Mirkovich, K. (2000). International Economics, Trakia-M Publishing House: Sofia.

Mirkovich, K. (2006). Problems of economic synergetics, Economic Thought Journal, 1, 3-32.

National Statistics Institut. https://www.nsi.bg/bg/content/2000/сателитнисметки-за-туризма

Porter, M. E. (1990). The Competitive Advantage of Nations. New York: The Free Press.

Rugman, A., \& Verbeke, A. (2003). Extending the theory of the multinational enterprise: internationalization and strategic management perspectives. Journal of International Business Studies, 34, 135-137. https://doi.org/10.1057/palgrave.jibs. 8400012

Rugman, A.M. (1979). International Diversification and the Multinational Enterprise, Lexington: D.C. Heath.

Rugman, A.M. (1981). Inside the Multinationals: The Economics of Internal Markets, New York: Columbia University Press.

Rugman, A.M. (2005). The Regional Multinationals, Cambridge, U.K.: Cambridge University Press.

Ryanair will fly to five more new destinations. https://www.dnevnik.bg/biznes/companii/2016/02/10/2702223_raiun eur_shte leti_po_oshte_pet_novi_destinacii_ot/

Tan, A. S. (2016). The ASEAN Experience, Northeast Asia and Beyond: Free Trade and Economic Integration. Cornell International Affairs Review, 10(1), 120-146. https://doi.org/10.37513/ciar.v10i1.487

The World Travel \& Tourism Council. (2018). Regional report, https://www.wttc.org/economic-impact/benchmark-reports/regionalresults/

UNCTAD. (2010). World Investment Report: Transnational Corporations and the Internationalization of R \& D.

UNWTO.

(2019).

Country

Fact

Sheet.

https://www.unwto.org/statistics/country-fact-sheets 
Gorcheva, T. Internationalization of Bulgarian Tourism Business

Uzunova, Y. (2004). Strategic marketing activity-resilience of companies to change. Varna: Steno Publishing House.

World Economic Forum. (2007). The Travel \& Tourism Competitiveness Report Geneva, Switzerland. http://www.weforum.org/en/initiatives/gcp/Traveland

WTTC Regional reports. (2018). https://www.wttc.org/economicimpact/benchmark-reports/regional-results/

WTTC. (2017). Maximizing Opportunities for Business Travel Growth. White paper, https://www.wttc.org/publications/2017/p4g-whitepaper-maximising-opportunities-for-business-travel-growth/

WTTC. (2021). Annual Economic Impact Research. https://wttc.org/Research/Economic-Impact 